\title{
JURGIS AMBRAZIEJUS PABRĖŽA - ŽYMUS BOTANIKAS, FARMACININKAS, LIAUDIES GYDYTOJAS
}

\author{
Janina Valančiūtė \\ Lietuvos medicinos biblioteka
}

\author{
Raktažodžodžiai: botanikas, farmacininkas, liaudies \\ gydytojas, medicinos raštai.

\section{Santrauka}

2021 m. sausio 15 d. sukako 250 metų, kai Večiuose, Skuodo rajone, gimè vienas iškiliausių XIX a. švietėjų, botanikas, liaudies gydytojas, pranciškonas, kunigas Jurgis Ambraziejus Pabrèža.

Vilniaus universitete gavęs teorinius pagrindus, bet studijų nebaigęs, J. Pabrèža grįžęs į Žemaitiją savarankiškai studijavo mediciną ir gamtos mokslus. Susikonspektavo 9 tomų „Bendrajị medicininị chirurginį žodyną“, iš kurio susidarè savo praktikai reikalingą rankraštinị vadovą. Būdamas kunigu ir dažnai lankydamas ligonius, stengèsi jiems padèti teikdamas medicininę pagalbą. Pradèjo domėtis gydymu žolelėmis - būdu, kuris buvo kiekvienam prieinamas. Naudojosi Simono Sirenijaus „Žolynu“. Buvo išvertęs Peterburge išleistą knygelę „Kaip reik apseiti su ligoniais ten, kur nėra daktarų“. J. Pabrèža ne tik rašè apie ligas, bet ir siūlè jų gydymo būdus, pateikẻ vaistų receptus. Iš viso yra išlikę 17 J. Pabrėžos rankraščių medicinos klausimais, kuriuose aprašomos dažniau pasitaikančios ligos, jų simptomai, gydymas. Paminėtini „Namų vaistine““, „Apie slogas plaučių“, „Kaip yra taisomos vaistų medžiagos“, „Apie kaltūną“, „Apie šiltinę“, „Augalai, naudingi gydymui“, ,Vaistai nuo geltonligès“, „Epilepsijos gydymas“ ir daug kitų.

Reikšmingi mokslui jo botanikos darbai, kurių rankraščių išliko apie 50, lietuvių - lotynų botanikos žodynas, augalų morfologijos lietuvių terminų žodynas, apie 800 augalų rūšių herbariumas. Didžiulis enciklopedinio veikalo „Taislius augyminis“ rankraštis ịtrauktas ị UNESCO programos „Pasaulio atmintis“ Lietuvos nacionalinị registrą kaip nacionalinès reikšmès dokumentinio paveldo objektas.

Savo raštus J. Pabrėža paskyrė tiems, kurie ,arti neturi vaistinès bei galimybių pasitarti su gydytojais, ir kurie ne tik gyvendami skursti, bet ir per anksti mirti turi“.

\section{Ivadas}

2021 metai Lietuvoje paskelbti vieno iškiliausių X1X a. švietėjų, botaniko, liaudies gydytojo, pranciškono, kunigo Jurgio Ambraziejaus Pabrėžos metais. Tai ịvairiaplanè asmenybè - pirmasis Lietuvos floros tyrinètojas, žemaitiškos terminologijos kūrèjas, mėginęs igyvendinti bendrinès žemaičių kalbos idėją.

J. Pabrèžos augalų sąvadas „Taislius auguminis“ - pirmasis mokslinis veikalas, kuriame vartojama žemaičių kalba. Paprastai tais laikais lietuviai raštams rinkdavosi lotynų arba lenkų kalbą. Augalų sąvado rankraštis įtrauktas į UNESCO programos „Pasaulio atmintis“" Lietuvos nacionalinị registrą, kaip nacionalinès reikšmès dokumentinio paveldo objektas.

Anot istoriko Liudo Jovaišos, jeigu Jurgị Pabrèžą gretintume su Kristijonu Donelaičiu, kuris užsièmė praktiniais darbais, tačiau neturèjo mokslinio mąstymo. Pragmatinis jo meistravimas, domėjimasis gamtos reiškiniais būdingas dar senajam pasauliui, o Jurgis Pabrèža pretendavo kurti rimtą mokslą, labiau priklauso Apšvietos epochai [1]. Jis rinko herbariumą, po 1831 metų sukilimo pradejjo aprašyti augalus pagal Karlo Linėjaus sistemą.

J. Pabrèža atsiskleide ir kaip liaudies menininkas. Jis nupiešè ir iš augalų suklijavo Dievo Apvaizdos paveikslą. Tape namuose pasigamintais dažais. Rinko žinias apie dažus, jų sudètị ir mokè žmones gamtiniais dažais dažyti namų apyvokos daiktus, piešti ir net tapyti. Kūrẻ eiles, kurios tapo dainomis.

Prieš 250 metų gimusio žemaičių kunigo vardas prisimenamas iki šiol. Kretingos gyventojai lanko Pabrėžos kapą, meldžia užtarimo nuo ligų ir nelaimių, laiko jị šventuoju. Broliai pranciškonai dar prieš karą prie kapo pastatė koplytėlę ir pradèjo rinkti medžiagą tèvo Ambraziejaus beatifikacijai. Antrasis pasaulinis karas šị darbą nutraukè, dokumentai dingo.

Darbo tikslas - apžvelgti J. Pabréžos darbus botanikos ir medicinos srityje.

\section{Tyrimo medžiaga ir metodai}

Straipsnio problematika nagrinèta pasitelkus žmonių gyvenimą ir veiklą analizuojanti biografinị metodą. $\mathrm{Pa}-$ 
naudoti Lietuvos mokslų akademijos Vrublevskių bibliotekoje, Lietuvos medicinos bibliotekoje ir Nacionalineje Martyno Mažvydo bibliotekoje saugomi leidiniai, portalo epaveldas.lt kolekcija ir laisvos prieigos šaltiniai internete.

\section{Tyrimo rezultatai}

Jurgis Pabrèža gimè $1771 \mathrm{~m}$. sausio 15 d. Večiuose, Skuodo rajone. Augo septynių vaikų šeimoje. Tẻvas buvo ūkininkas, laisvas nuo baudžiavos. Mokyklą baigė Kretingoje. Daugelyje šaltinių nurodoma, kad 1791-1794 metais Vilniaus universitete (tada - LDK vyriausioji mokykla) jis mokèsi istorijos, medicinos, botanikos, chemijos, teisès ir teologijos. Disciplinų sąrašas labai įvairus. Pats J. Pabrèža minejjo universiteto profesoriaus gydytojo Ferdinando Špicnagelio botanikos paskaitas, kurios lèmè jo pasirinkimą ir aistrą botanikos mokslui. Išmoko lotynų, graikų, lenkų, vokiečių, rusų ir baltarusių kalbas, tačiau jam nebuvo lemta baigti studijas universitete. J. Pabrèža dalyvavo T. Kosciuškos vadovaujamame sukilime, po kurio ị Vilnių nebegrịžo. 1794 m. ịstojo ị kunigų seminariją Varniuose. 1796 m. įšventintas kunigu, nes prieš tai buvo studijavęs teisę, teologiją ir Šventajj Raštą. Du dešimtmečius po keletą metų kunigavo Šiluvoje, Raudènuose, Tveruose, Plungeje, ilgiau - Kartenoje. $1816 \mathrm{~m}$. įstojo ị pranciškonų vienuolyną, o $1817 \mathrm{~m}$. prièmè ịžadus. Nuo vaikystès jo gyvenimas buvo susietas su pranciškonais. Dẻde buvo pranciškonas. Pats Jurgis, mokydamasis Kretingoje, gerai pažinojo brolių gyvenimą.

Kretingos vienuolyne jis praleido paskutinius gyvenimo metus (iki 1849 metų). Buvo paskirtas Kretingos pranciškonų mokyklos mokytoju ir kapelionu. Mokè lotynų kalbos, o gamtos mokslus su dideliu entuziazmu dèstè ne tik klasèje, bet ir gamtoje. Pabrėžos gamtos pamokos, ypač botanikos, buvo labai įdomios. Anot Juozo Tumo-Vaižganto, jis mokejjo savo žinias perduoti ir gamtos mokslo meilę įkvèpti, apžiūrinėdavo kiekvieną augalèlį, pradedant nuo šimtamečio medžio iki smulkiausio kirmino. Vienuolyno kiemelyje Pabrěža buvo ịsirengęs įvairių gèlių ir naudingų augalų sodelị. Sèklų gaudavo iš Vilniaus universiteto botanikos sodo. Pabrěžos sodeli broliai pranciškonai išsaugojo net iki 1963 metų.

J. Pabrezža daug keliavo po apylinkes, rinko istorinę, etnografinę medžiagą, botanikos eksponatus. Jo gyvenimo Kretingoje laikotarpis pasižymejjo medicinos ir botanikos krypties darbais.

Vilniaus universitete gavęs teorinius pagrindus, bet studijų nebaigęs J. Pabrèža, grįžęs į Žemaitiją, savarankiškai studijavo mediciną ir gamtos mokslus. Pradèjęs kunigauti Kretingoje, J. Pabrèža greitai pagarsèjo kaip gydytojas. Turèdamas daug medicinos žinių, savo pamoksluose ir lankydamas ligonius duodavo patarimų bei teikdavo pagalbą. Pasak Juozo Tumo-Vaižganto, nors Pabrezža turejjo gerą spintą vaistų, tačiau gydydavo kone vienomis žolèmis. Jo celè ir visas koridorius kvepèjo žolèmis [2]. Vaistus daugiausia gamindavo iš surinktų žolelių. J. Pabrèža naudojo ir mineralus, sierą, salietrą, bei tolimųjų kraštų augalus, tarp kurių paminètas ženšenis. Juos pirkdavo vaistinèse. Žmonès nuolat kreipèsi ị jị pagalbos. Už gydymą niekada neimdavo atlyginimo, nesiūlè brangių, neprieinamų vaistų. İ užkalbètojus žiūrèjo neigiamai, o su žolininkais bendravo. Stengèsi žmones atgrasinti nuo prietarų ir burtų.

Apie savo medicininę praktiką J. Pabrèža rašè Vilniaus universiteto profesoriui Johanui Fridrichui Volfgangui: „Tapęs pasauliniu kunigu ir eidamas šias savo luomo pareigas, dažnai turedavau lankyti ịvairius ligonius, neturinčius jokios medicininès pagalbos, o jų kančios labai mane jaudindavo, tad norejjau nors šiek tiek padèti jiems gydytis. Tačiau, nežinant defektų, neįmanoma buvo jiems ką gera padaryti: dèl to ịsigijau Avorko „Sisteminès - praktinès medicinos veikalą“, kun. Dargošo išverstą ị lenkų kalbą. Tik čia pamačiau daug gydomųų medžiagų iš augalų pasaulio, o jų nepažinau, tai buvau priverstas parsisiųsdinti kun. Kliuko „Augalų žodyną“ ir S. Jundzilo „Augalų aprašymą“. Tačiau, kadangi neturejjau jokio šios specialybès vadovo, kuris būtų atskyręs vaistinius augalus nuo nevaistinių, buvau priverstas iš eilès rinkti ir determinuoti visus augalus, kuriuos tik pastebejau pievoje, ir tai tik tam, kad pažinčiau ir atrinkčiau vaistinguosius. Teisybè, kai kurių augalų savybės mane dargi nudžiugino, bet kiek tai iš manęs pareikalavo triūso, gal tik tas supras, kas pats šioje srityje plūkèsi be jokio vadovo“ [3]. J. Pabrèža patarè gydyti atsargiai ir rūpestingai. Kadangi ta pati liga turi daugeli savybių, tai reikia jas tinkamai ištirti, stebėti, ar gali ta ar kita vaistažolè naikinti ligos savybes ir tik tuomet pradèti gydyti nurodytu augalu.

Kretingoje J. Pabrèža susikonspektavo 9 tomų „Bendrajį medicininį chirurginį žodyną" ir iš jo susidarè savo praktikai reikalingą rankraštinį vadovą. Buvo susikonspektavęs Simono Sirenijaus „Žolyną“ ir jo pagrindu lenkų kalba parašè „Kai kurių augalų gydomosios savybès ir tų augalų panaudojimo būdai ịvairių ligų atveju“. İžangoje kreipiasi i skaitytoją: „Priimk, malonus skaitytojau, ši trumpą mano darbą, kuriame rasi paprasčiausius būdus, kaip reikia gelbèti neturtinguosius ịvairių ligų atvejais paprastomis priemonèmis - beveik visiems pažịstamomis vaistažolèmis... [4 ]“. Autoriaus vadinamą trumpą darbą sudarè 246 smulkiai ranka rašyti puslapiai, kuriuose aprašyti 234 augalai. Pradžioje abėcèlès seka pateikiamas vaistingưjų augalų sąrašas lotynų, lenkų ir žemaičių kalbomis. Toliau - ligų sąrašas, vadinamas „Rejestru“. Abècèlès seka išvardinta daugiau kaip 900 susirgimų, negalavimų, kosmetinių trūkumų. Nurodoma, kokias vaistažoles vartoti. Aprašydamas kiekvieną augalą, nurodo, kokiomis savybėmis pasižymi ir kurias ligas juo galima 
gydyti. Pateikia vaistų pasigaminimo receptus. Kartais net tiksliai nurodo, kiek vaistažolių pasverti. Medžiaga išdėstyta sistemingai, populiariai, kiekvienam suprantama kalba. Pratarmėje pažymi, kad S. Sirenijaus augalų aprašymai yra pasenę, todèl augalus sugrupavo pagal naują K. Linejjaus sistemą. Jis pastebejo, kad tuo metu vartojamos vaistų dozès dažnai būdavo per didelès. Jis ịvedè skirtingas dozes ir nurodè, kad jo veikale nurodytos dozès tinka asmenims nuo 20 iki 50 metų. Jaunesniems ir vyresniems dozès turi būti mažinamos proporcingai jų amžiui.

Dar Kartenoje buvo išvertęs Peterburge išleistą knygelę „Kaip reik apseiti su ligoniais ten, kur nėra daktarų“. Tikriausiai, galvojo šią knygelę išspausdinti ir paskleisti žmonèse, bet, kaip ir kiti jo darbai, vertimas liko rankraštyje. Išverte iš lenkų kalbos Danieliaus Branto farmakologijos vadovèliui prilygstantị didelį veikalą „Trumpa medikamentų specifikacija, tinkamomis informacijomis aprobuota, kuri su pasisekimu gali būti naudojama ne tik kasdien sveikatai palaikyti, bet ir kasdieniniame gyvenime“" Jame išvardinamos ligos ir nurodoma, kokius vaistus vartoti.

Knygelëje „Namų vaistinèlè“ aprašomos dažniau pasitaikančios ligos, jų gydymo būdai ir pateikiami receptai, kaip iš augalų namuose pasigaminti vaistus. Pateikiama žinių, kaip rinkti vaistažoles, jas paruošti, gaminti tinktūras, ekstraktus, aliejus ir kt. Tekstas iliustruotas paties autoriaus augalu brèžiniais. Kiekvieno skyriaus pradžioje pritaike kokią nors patarlę. Prie žadinančių apetitą vaistų rašo: „Apetito neturi tie, kurie ilgai miega, dažnai čerką gurkšnoja, nuo darbelio bèga [5]“. Pamokanti patarlè: „Vaistai ir valgiai vienodai vertingi, bet per daug panaudoti sveikatai kenksmingi [6]“.

Straipsnelyje „Apie sveikatą, kaip sveikam ilgai gyventi“ nurode receptus, davė praktiškų patarimų.

Dalis Pabrèžos raštų surinkta rankraštyje „Spindulèlis“.

Rankraščiuose „Apie slogas plaučiu““, „Kaip yra taisomos vaistų medžiagos“, „Apie kaltūną“, „Apie šiltinę“, „Augalai, naudingi gydymui“, ,Vaistai nuo geltonligès“, „Epilepsijos gydymas“ ir daugelyje kitų, Pabrěža rašè, kaip atpažinti ligas, kaip slaugyti ligonius. Dalinosi žiniomis, kurias buvo igijęs savo darbo praktikoje.

Iš viso išliko 17 Pabrèžos rankraščiu medicininiais klausimais, kuriuose aprašomos dažniau pasitaikančios ligos, jų simptomai, gydymas. J. Pabréža parengé apie 50 darbų botanikos tema. Lotynų - lietuvių kalbų botanikos žodynas, Augalų morfologijos lietuvių terminų žodynas.

Didžiausias jo darbas - unikalus Žemaitijos augalų aprašymas „Taislius auguminis“ („Augalų sistema“), kuriame apibūdino 643 augalus. Remdamasis K. Linejjaus sistema, J. Pabrèža pirmasis aprašè Žemaitijos augmeniją žemaičių kalba. Žodžius rašè taip, kaip jie buvo tariami žemaičiu kasdienèje kalboje.

\section{Išvados}

1. J. Pabrèža paliko daugiau kaip 4 tūkst. puslapių rankraščių rašinių gamtos mokslų, medicinos klausimais ir žodynų. Iš jų 2588 puslapiai rašyti lietuvių kalba, o 1569 - lenkų ir lotynų kalbomis. Beveik visi jo raštai taip ir liko rankraščiuose. Daug J. Pabrèžos darbų yra suskaitmeninta, juos galima rasti virtualioje kultūros paveldo svetainejje www.epaveldas.lt.

2. Dauguma J. Pabrèžos darbų yra šviečiamojo pobūdžio. Savo rankraščius jis skyre tiems, kuriuos gydè. „Skiriu savo darbą patogumui ir gelbėti sveikatai tų, kurie arti neturi vaistinès bei galimybiu pasitarti su gydytojais ir kurie ne tik gyvendami skursti, bet ir per anksti mirti turi [7]".

3. J. Pabrèža ne tik kalbejjo, bet ir mokè, pamokslus sakè, botanikos ir medicinos veikalus rašè kretingiškių žemaičių tarme. I pažistamo lenko ar sulenkèjusio lietuvio pastebejjimą, kad nèra prasmès gaišti laiką rašant lietuviškai medicinos ir botanikos veikalus, nes yra daug geros šios srities literatūros lenkų kalba, Pabrèža atsakè: „Kam tie lenkai gaišina laiką ir rašo lenkiškai: juk tiek daug yra puikios tos rūšies literatūros vokiečių ir kitomis kalbomis [8]““. Pabrèža, kurdamas pirmajị augalų sąvadą žemaičių kalba, iškèlė žemaičių kalbos sistemingos rašybos būtinybę. Savo botanikos „Žolininke“ augalus, neturinčius žemaitiškų vardų, pavadino mitologiniais lietuvių dievų vardais. Kai kurie jo sukurti augalų pavadinimai išnyko, kiti ịsitvirtino. Pvz., guboja ir raganè vartojami iki šiol.

4. J. Pabrèžos darbai grąžina žmogų i gamtoje slypinčius gyvybę ir sveikatą saugančius šaltinius. „Kaip gydytojas ir patarejas Pabrèža nesiūlo neprieinamų vaistų - jis tik kalba apie tas vaistingas priemones, kurios yra čia pat netoli namų - darže, paežerèje, pievoje ar lauke“, - Romoje išleistoje monografijoje rašo istorikas Viktoras Gidžiūnas. - „Kiti Pabrèžos rankraščiai liudija, kad jis, nors ir nebaigęs medicinos mokslų, turèjo platų medicininį išsilavinimą, kuriam ịgyti labai daug pastangų padejjo. Jo gydytojo praktika reikalavo pastovaus darbo ir labai daug jègų prisimenant, koks reiklus sau jis buvo ir kiek daug pareigų visą gyvenimą turejjo [9]“".

\section{Literatūra}

1. Kunigui Jurgiui Ambraziejui Pabrèžai - 250: žemaičių šviesuolio užmojai nesiliauja stebinti iki šiol. https://www.lrt.lt/ naujienos/kultura/12/1317178/kunigui-jurgiui-ambraziejuipabrezai-250-zemaiciu-sviesuolio-uzmojai-nesiliauja-stebintiiki-siol

2. Vaižgantas. Raštai. T.2. 1929; 68.

3. Laiškas prof. Wolfgangui. Lietuvos mokslų akademijos biblioteka, F7 - 309: cit. pagal: Gidžiūnas V. Jurgis Ambraziejus Pabrèža (1771 - 1849), 1993; 211.

4. Pabrěža J. Skutki lekarskie niektórych roślin i sposób uzywanie 
tychźe roślin w różnych chorobach, wyjęte z dzieła Symona Syreniusza Doktor. Akad. Krakowskiei przez xiędza Jerzego Pabrėža altarysty Korcianego roku 1814 w Korcianach. Cit. pagal: E. Kanopka. Jurgis Pabrèža - garsus Žemaitijos gydytojas, įžymus gamtininkas, pirmasis Lietuvos farmakognostas, in: Medicina. Lietuvos TSR aukštųjų mokyklų mokslo darbai, XII, 1970; 40.

5. Pabrèža J. Apteczka domowa, 1793; 343. Cit. Ibid, 43.

6. Jurgis Pabrèža, op. cit., p. 343. Cit. Ibid, 43.

7. Jurgis Pabrèža, op. cit., p. 343. Cit. Viktoras Gidžiūnas, 213.

8. Viktoras Gidžiūnas. Šv. Ambraziejus Pabrèža - Šv. Pranciškaus dvasios sūnus. Aidai, 1976; 8: 362-369.

9. Viktoras Gidžiūnas, op. cit., 213.

\section{JURGIS AMBRAZIEJUS PABRĖŽA AS A PROMINENT BOTANIST, PHARMACIST AND FOLK PHYSICIAN} J. Valančiūtè

Keywords: botanist, pharmacist, folk physician, medical texts. Summary

The date of 15 January 2021 marks 250 years from the birth of the would-be botanist, physician, one of the most prominent educators of the 19th century, Franciscan Father Jurgis Ambraziejus Pabrèža in Večiai, Skuodas District, Lithuania.

The purpose of the article is to review the work of this multitalented personality in the field of botany and medicine. Having learned theoretical basics at Vilnius University but without completing the studies, Pabrezža returned to Samogitia and studied medicine and natural sciences individually. He summarised the nine-volume Bendrasis medicininis chirurginis žodynas (General Medical and Surgical Dictionary) into a manuscript guide for his personal use. When serving as a priest and often visiting patients, he tried to provide them with medical assistance and, therefore, became interested in herbal remedies that cost nothing and were at everyone's hand. In his medical pursuits, Pabrezža referred to Žolynas (Herbs) by Simonas Sirenijus and also translated the booklet How to Treat Patients When There Are No Doctors published in St. Petersburg. In addition to describing diseases, Pabrèža recommended treatments and offered medical recipes. The case in point is Namų vaistinè (Home Remedies); Apie slogas plaučių (About Lung Diseases); Kaip yra taisomos vaistų medžiagos (How Therapeutic Substances Are Prepared); Apie kaltūną (About Polish Plait); Apie šiltinę (About Typhus); Augalai, naudingi gydymui (Herbs Useful for Therapy); Vaistai nuo geltonligès (Remedies Against Jaundice); Epilepsijos gydymas (Treatment of Epilepsy), and a number of other writings. A total of 17 manuscripts on medical matters by Pabrèža have survived with descriptions of more common diseases, symptoms and treatments. The research has benefited from his botanical studies with over 50 surviving manuscripts, the Lithuanian-Latin botanical dictionary, the dictionary of Lithuanian terms of plant morphology, and the herbarium of about 800 plant species. The massive manuscript of the encyclopaedic work Taislius augyminis (System of Plants) has been included in the Lithuanian National Register of the UNESCO Memory of the World Programme as an object of documentary heritage of national significance. Pabrèža aimed his medical texts at those who 'are far away from a pharmacy and opportunities to consult a doctor and who, apart from living in poverty, have to die too early as well'.

Correspondence to: Janina.Valanciute@1mb.1t

Gauta 2021-05-18 